\title{
The Advantage of Preventing Unfair Competition through an Administrative Body
}

\author{
By W. H. S. Stevens, Ph.D. \\ Washington, D. C.
}

I $\mathrm{N}$ a study of the Federal Trade Commission and Clayton Acts made shortly after their passage, ${ }^{1}$ the writer, taking a generally favorable view of the legislation, expressed two opinions. The first was that perhaps "the most important power of the commission and the one most likely to make it an important administrative authority was that over unfair competition." The second was to the effect that there was some administrative advantage in preventing unfair methods of competition through the commission with direct and final appeal to the Circuit Court of Appeals instead of leaving the enforcement to the ordinary mechanism of the Department of Justice and the courts. The conclusions thus expressed are, in the light of subsequent events, far from requiring any modification. On the contrary the scope of the commission's work and the results obtained by this body serve to emphasize their correctness and impress upon one the sound wisdom of the legislation which provided for administrative control of unfair methods of competition.

Of the fact that the legislation was needed there can be little or no doubt. ${ }^{2}$ The volume of applications for complaints which has been received by the commission is alone, in all probability, sufficient evidence of this fact. ${ }^{3}$ If this is not a satisfactory criterion any survey of the character of the complaints issued will convince unprejudiced persons. While this is perhaps not the place for indicating the nature of the methods against which the commis-

\footnotetext{
${ }^{1}$ Stevens, the Trade Commission Act, American Economic Review, December, 1914, Vol. IV, p. 840, the Clayton Act ibid. Mch. 15, Vol. V, p. 38.

${ }^{2} \mathrm{Cf}$. arguments of the writer over legislation on this subject in Articles on Unfair Competition in Political Science Quarterly, June and September, 1914, Vol. XXIX, pp. 282 and 460.

${ }^{3}$ Up to November 21,1918 , about four years after its creation, the commission had received 876 applications for complaints, a rate of approximately 225 a year. $C f$. W. B. Colver, Chairman, Address before the American Specialty Manufacturers' Association, Cleveland, November 21, 1918.
} 
sion has taken action, it may not be inappropriate to enumerate some of them for the benefit of those who may be unfamiliar with the activities of this body in this direction. In the fiscal year ending June 30, 1918, the commission issued 153 complaints covering a wide variety of unfair practices. These included, among others, exclusive contracts, maintenance of resale prices, commercial bribery, threats of patent infringement suits, passing off, misrepresentation, false advertising, accumulative rebates, tying contracts, intimidation of competitors and customers of competitors, inducing cancellation of orders of customers from competitors, bogus independents and manufacturers' guarantees against declines of dealers' stocks.

Assuming, therefore, that the legislation was necessary, any one of at least three methods of procedure might conceivably have been adopted by Congress for the elimination of these abuses. In the first place unfair methods of competition might have been declared unlawful and the injured individual or organization given a private right of action against the offending party, permitting him to sue for an injunction and also for the damages sustained as a result of the alleged unfair acts.

\section{Court Decisions on Unfair Competition}

The objections to such a form of procedure are fairly obvious. The most important one, perhaps, is the construction and interpretation which might be placed upon such an act by the courts. Prior to the passing of the Federal Trade Commission Act there was, it should be borne in mind, a considerable body of decisions on the matter of unfair competition. Broadly speaking, such decisions were of two classes, i.e., those rendered under the old common law and those handed down in connection with cases under the Sherman Act. The common law decisions, however, related very largely to such matters as passing off, misrepresentation, etc., and while the course of these decisions, especially in the last ten years, had shown some tendency towards the expansion of this classification, the common law interpretation of unfair competition was, after all, a decidedly restricted one. Following the passage of the Sherman Act the legal significance of unfair competition may be said gradually to have broadened to include a number of methods which were frequently employed by large 
and powerful organizations for the purpose of crushing their competitors. Repeatedly the courts of the United States enjoined these practices upon the sound theory that they restrained trade and resulted in monopoly.

The methods thus prohibited by the courts in the Sherman Act cases differ from those forbidden in actions under the old common law perhaps chiefly in the fact that they usually involved no element of moral turpitude. In the old common law cases on unfair competition such factors as fraud, deceit and misrepresentation were present in probably the majority of instances, and in all the balance the invasion of a competitor's legal rights. The acts prohibited under both the common law and Sherman Act rules resulted in injury to competitors, but the bases upon which the methods were prohibited were different. In the old common law cases the element of moral turpitude or the invasion of a competitor's legal rights were in practically all cases responsible for the court's injunction; in the cases under the Sherman Act the fact that the acts resulted in restraint of trade or attempted a monopoly led to the injunctions. In other words, even though it be admitted that a considerable expansion took place in the law of unfair competition in more recent years, doubt may be expressed as to whether, under the decisions of the courts up to the time of the passage of the Federal Trade Commission Act, it would have been possible to have secured a judgment in any court against any practice that did involve at least one of the above mentioned elements, i.e., moral turpitude, the invasion of a competitor's legal rights or restraint of trade and monopoly; and this was probably true even though it might be clearly shown that the method in question adversely affected competitors.

\section{Prevention Through Private Right of Action}

The courts, as everybody knows, are somewhat slow to change. They are and should be conservative and for this reason alone, if for no other, the wisdom of simply forbidding unfair methods of competition and leaving to the individual the entire matter of enforcing his rights under such a statute would be open to serious question. The law is a process of evolution. It changes slowly and while it is quite possible to grant that the courts ultimately will develop in all cases a body of law that leaves little to be desired from the standpoint of justice, it requires years, decades and 
even centuries at times for this evolution to take place. To have employed the method under discussion for the purpose of preventing unfair methods of competition would have been to run the grave danger of a somewhat narrow and restricted construction of this term which might continue for many years during which the judicial interpretation of the act slowly evolved.

Secondly, under this method of enforcement the matter of construction must necessarily have been left in the hands of a considerable number of courts, either district courts or circuit courts of appeal. Since one court is more conservative or more progressive than another, there is grave probability that no consistent construction of the law would have appeared for some time since each court would arrive at its conclusions independently upon the basis of the facts before it. These facts would vary from district to district and the theories of the parties in the cases involving the same points before different courts would necessarily show the utmost diversity. Because of this situation different courts might arrive at diametrically opposite conclusions in cases involving the same methods and practices. The law as a consequence would in all probability be in a state of considerable confusion for some time in the future.

The third and most important objection to the method of preventing unfair methods of competition through the private right of action lies in the difficulty which the private individual would have in procuring the necessary evidence in a great many cases. The organizations most likely to suffer from unfair practices are the small and weak though often efficient concerns struggling for a market. Many unfair practices involve the most complicated sets of economic facts-costs, profits, margins, stocks on hand, production, sales, prices, etc. The small organization cannot usually command the legal processes necessary to obtain these facts and even if it could, its financial resources are seldom such as to enable it to do so or to secure the legal, economic, accounting and statistical assistance frequently necessary to enable it properly to prepare and present its case before the court. In a good many instances it cannot be doubted that competitors submit to practices which they consider objectionable and unfair simply because they know that it would involve so heavy an expense to contest them without any certainty of their being able to win their cases. 
Finally, and by no means the least important consideration against the method of private right of action, is the fact that methods of competition very frequently involve matters of grave public interest which makes desirable affirmative action by the government itself to protect the public interest.

For the reasons enumerated, therefore, it may be greatly doubted that any adequate protection would be afforded to the relatively small organization against the unfair practices of competitors, could injured parties only secure protection against such methods through private right of action ${ }^{4}$. It may therefore be concluded that the results obtainable by the above mentioned method of procedure in unfair method of competition cases would be far from satisfactory.

\section{Prevention Through Department of Justice}

A second method of procedure which might conceivably have been attempted for preventing and eliminating unfair methods of competition would have been to turn this whole matter over to the Department of Justice under a method of procedure similar to that employed in handling violations of the Sherman Act. Such an arrangement would undoubtedly possess important advantages as compared with the private right of action in preventing unfair methods of competition.

In the first place the general public interest would be better safeguarded by provision for affirmative governmental action than would be the case were the right of action merely a private matter. Secondly, there would not exist that same lack of adequate protection to small organizations on account of the expense involved in the prosecution of private suits as would obtain where such suits were the sole protection against unfair methods of competition.

- Some indication of the possible lack of effectiveness of the private right of action alone or compared with administrative action may perhaps be obtained by considering the results of the operation of Sections 2 and 3 of the Clayton Act which forbid price discriminations and exclusive and tying arrangements respectively, both of which methods may properly be regarded as unfair methods of competition. The act also gives parties suffering from these methods a private right of action with treble damages for injuries suffered in addition to the authority which the Trade Commission has to prohibit these practices. A very considerable number of complaints have been issued by the commission under these two sections but the proportion of suits which have been brought by individuals are exceedingly few. 
Despite these obvious advantages in favor of the method under discussion as compared with the method of enforcement through the individual right of action, many of the same objections as were suggested to the latter course of procedure may also be raised against the former.

The Department of Justice is primarily and in the last analysis a legal organization. It would appear reasonable to expect, therefore, that the construction and interpretation of the term "unfair methods of competition" adopted by such an organization would be very similar to that of the courts. It would also appear not incorrect to assume that the concepts and ideas of this department with reference to this matter would, relatively speaking, enlarge but slowly as the writer has indicated would probably be the case were the construction of this act left entirely in the hands of the courts. Moreover, if as is the case with the Federal Trade Commission Act final decision as to the legality of various practices rested with the Circuit Court of Appeals except upon certiorari, there would almost of a certainty exist the same confused state of the law owing to different decisions in different jurisdictions on the same method of competition as would exist were it attempted to prevent unfair competition through the private right of action.

Such a possible conflict in decisions, however, would probably exist to a less extent under enforcement through the department than under prevention by private right of action owing to the fact that one central organization, the Department of Justice, would handle all cases and would presumably be obliged to develop a certain logical theory or theories of this law which would be consistently employed in the preparation and trial of cases in which the department took action. This is an advantage of no little importance in favor of this method as compared with the one previously discussed. At the same time, as already indicated, many of these cases involve numerous economic, accounting and statistical as well as legal principles and facts and even the Department of Justice is not well equipped to handle the first three matters. Moreover, the Department of Justice has no such broad visitorial powers or authority to obtain reports as is possessed by the Federal Trade Commission. These powers enable the latter body before the actual trial of cases to obtain access to correspondence, production, cost, sales, price and other records 
both of the party complained of and its competitors and also to require reports covering any material factor not only relating to the business of the party complained of but also the business of its competitors. It is, of course, possible for the department to subpœna witnesses in court, to call for the production of books and papers, etc., etc., but the legal rules in regard to subpœnas are rather strict. A subpona, in order to be good, must as a rule be reasonably specific; the documents requested must be shown to be relevant and the amount of data required to be produced must be not unreasonable. Subpœenas are not issued for documentary data merely for the purpose of determining whether or not certain evidence is contained therein. In other words, subpœnas issued for the purpose of enabling a "fishing expedition" are not granted by any court.

Without ability to go directly to correspondence files, accounts, records, etc., and to go through them as thoroughly as may be necessary in order to determine the effect of a particular practice or practices, any organization is likely to be greatly handicapped in determining the fairness or unfairness of particular methods. While a certain amount of such work can be done through the use of subpœnas, it is not always possible on account of the technicalities in connection therewith so to draft such subpœnas as to secure the information required. Moreover it frequently requires a broad general grasp of economic principles as well as expert accounting and statistical analysis to determine what facts are to be looked for and where they are to be found and how they should be analyzed,--for in many cases the concerns themselves would be unable to advise either as to what data to obtain or methods of analysis to employ in order to show the effects of certain practices.

All these facts would appear to be against the placing of jurisdiction over unfair competition in the hands of the Department of Justice rather than in those of an administrative body. The fact that the department possesses no force of economic, statistical and accounting experts would seem to argue that there might be a neglect of these economic, statistical and accounting aspects and elements in the determination of unfair methods of competition. The department's lack of broad visitorial powers would inevitably tend to emphasize this possibility for the reason that in the ab- 
sence of such powers it is frequently impossible to obtain the requisite, economic, statistical and accounting facts necessary to prove the effect of various practices upon competitors. Moreover, the inability of the department to require statistical accounting and other reports from concerns not parties to complaints would be certain greatly to handicap it in procuring the best evidence in many cases as to the effect of certain methods.

\section{Prevention Through an Administrative Body}

The third possible course of procedure that was open to Congress for preventing unfair methods of competition was to do exactly what was actually done, i.e., place the authority to enforce the act in the hands of an administrative body. The Federal Trade Commission Act declares unfair methods of competition to be unlawful and lays upon the Federal Trade Commission the duty of preventing the same.

When the commission believes that an organization is utilizing an unfair method of competition and it appears to it that a proceeding in this respect would be in the interests of the public, the commission issues and serves a complaint stating the charges and giving notice of a hearing at least thirty days after service. The party complained against has the right to appear and show cause why an order should not be entered requiring him to desist from the violation of law charged in the complaint. Any party, upon good cause being shown, may be allowed by the commission to intervene and appear.

If, upon hearing, the commission believes the method of competition in question to be prohibited, it makes a report in writing stating its findings as to the facts, and issues an order to the party complained against ordering him to cease the use of the method in question. The commission may modify or set aside its report or order at any time prior to the filing of the transcript of the record of the hearing with the Circuit Court of Appeals.

In order to enforce the order of the commission it is provided that, if it is not obeyed, the commission may apply to the Circuit Court of Appeals of any circuit where the method in question was used, or the party resides or carries on business, filing the tran. script of the record of the proceeding, including testimony. The court then takes jurisdiction, notifies the party, and has full 
power to enter a decree affirming, modifying, or setting aside the order of the commission. The findings of the commission as to the facts, however, are conclusive if supported by testimony. If either party applies to the court for leave to adduce additional evidence and can show that it is material and that there were good reasons why it was not introduced before the commission, then the court may direct that such additional evidence be taken before the commission. This body may then modify its findings or make new ones, and again file the results with the court (which findings are deemed conclusive if supported by testimony), together with the additional evidence with its recommendations, if any, for the modification or setting aside of its original order.

The judgment and decree of the Circuit Court of Appeals is made final, except that the Supreme Court may review upon certiorari. The jurisdiction of the Circuit Court of Appeals to enforce, modify, or set aside the orders of the commission is made exclusive and all such proceedings are given precedence over other cases and are required to be expedited in every way. The order of the commission or the judgment of the court to enforce the same cannot absolve anyone from liability under the anti-trust acts. Any party against whom an order of the commission is made may obtain a review upon an application to the Circuit Court of Appeals to set aside the order. ${ }^{5}$

The advantages of this method of procedure follow logically from the preceding discussion of the disadvantages of preventing unfair competition through the courts, and the Departnent of Justice and the courts. The first advantage is in the matter of the construction of the act.

\section{Administrative Construction of the Act}

As an administrative body the composition of the commission is likely always to be of such a character as to number among its five members men formerly engaged in different professions, businesses and occupations. There would, therefore, seem to be no particular reason why the commission should be bound by legalistic traditions which might possibly limit the construction of unfair methods of competition in such a way as to confine it to either the old common law interpretation or make it synonymous with

- Federal Trade Commission Act, Sec. 5. 
the Sherman Act or both. The interpretation of the statute should undoubtedly be broad enough to cover not only these practices but many more as well. ${ }^{6}$ The old common law rule, as already indicated, was relatively narrow in its application and methods of unfair competition though frequently enjoined in Sherman Act cases could probably never have been so prohibited unless such acts were in connection with a conspiracy, combination or agreement in restraint of trade or were sufficient to amount to an attempt to monopolize, even though competitors might be adversely affected by such methods. As stated, however, the construction of this act can and should extend over a much broader field than that which would be covered by the interpretations mentioned. ${ }^{7}$

Competition is in essence an economic matter in that it is a phenomenon of the economic world. From this standpoint, therefore, there must and should be economic as well as legal criterions for the determination of what constitutes fair and unfair competition. The commission has extraordinarily wide powers of investigation on its own initiative, the authority to examine books, papers and records of corporations and to make copies thereof and to require either annual or special reports of corporations engaged in interstate commerce. In pursuance of its powers it is authorized to make investigations of industry and to report thereon, and in such connection it has upon its staff in addition to its attorneys a large force of highly trained economists, accountants, and statisticians all of whom are available as circumstances may require for the analysis and study of unfair competition and who can at any time be employed for the purpose of conducting investigations into the economic effects of certain practices.

As a result of all these facts the commission should be in better position to lay down and develop sound standards for the operation of the competitive principle and to develop the lines along which the competitive process should be conducted than either the courts, or the Department of Justice and the courts together. It is noteworthy that the conduct of the work of the commission clearly indicates that that body recognizes the importance of the

${ }^{6} C f$. Stevens W. H. S., "Unfair Competition," Chicago, University Press, 1917.

${ }^{3}$ Cf.also Stevens "Unfair Competition." 
economic element in unfair competition. This appears not only in the organization of the commission's staff but also in some of the proceedings begun by it. In the commission's method of handling complaints, all such complaints after investigation go together with the evidence and the reports of the investigators thereon to a board of review. The function of this board is to review this evidence and these reports and make its own report and recommendations thereon to the commission which passes finally upon the cases. Throughout the entire history of the commission the composition of this board has included both economists and lawyers, the chairman in each case being a lawyer.

The so-called Old Dutch Cleanser and Sears Roebuck cases may be used as illustrations of cases in which the commission has apparently recognized the economic element in unfair methods of competition. In the Old Dutch Cleanser case the complaint was directed against the Cudahy Packing Company alleging as an unfair method of competition that the said company maintained resale prices on this product. The commission found:

(16) That the effect of the price fixing aforesaid has been and is: (a) To secure for respondent, The Cudahy Packing Company, on its "Old Dutch Cleanser," the trade of jobbers and other wholesalers, and especially the relatively higher cost and more inefficient jobbers and other wholesalers, constituting the bulk of the jobbing and wholesale trade, and to enlist their active support and coöperation in enlarging the sale of its price-maintained cleanser, to the prejudice of competing manufacturers who do not fix, require, or enforce the maintenance of resale prices upon their cleansers, thereby protecting such jobbers and other wholesalers against the price competition of other jobbers and wholesalers and especially the relatively lower cost and more efficient establishments;

(b) To tend to force manufacturers who do not fix, require or enforce the maintenance of resale prices and who compete with respondents in the sale of powdered cleansers, also to inaugurate and enforce a system of maintenance of resale prices upon their powdered cleansers, in order to offset the preference of jobbers and other wholesalers for respondent's price-maintained cleanser and to enable manufacturers who do not maintain resale prices upon powdered cleansers to compete upon more equal terms with respondent;

(c) To eliminate competition in prices among jobbers and wholesalers handling "Old Dutch Cleanser," thereby interfering with many such jobbers and other wholesalers, and especially the relatively lower cost and more efficient establishments in their sales of such cleanser at such prices as they may deem adequate and as are warranted by their costs, selling efficiency, and existing trade conditions;

(d) To compel the public, or such portion thereof as require or prefer "Old 17 
Dutch Cleanser" to pay prices therefor based on a gross-profit margin fixed, as aforesaid, according to the costs of the relatively higher cost and less efficient establishments, constituting the bulk of the jobbing and wholesale trade, instead of a price based upon the competition of jobbers and other wholesalers with widely varying stock turns, costs, and efficiency ${ }^{8}$

In the Sears Roebuck case the commission charged the Sears Roebuck Company with false and misleading advertising and with the sale of sugar below cost when such orders for sugar were combined with orders for other goods. The following quotations from the commission's brief in the Circuit Court of Appeals are worthy of note in this connection:

Petitioner has intended to take, and has taken, custom from many of its thousands of retail competitors, solely upon the basis of admitted misrepresentations of its goods, which, as already set forth, were distinctly intended and designed to procure business on the basis of such misrepresentations instead of upon the basis of quality, service and price. The result was inevitably to deprive petitioner's retail competitors of business and to weaken and render less effectual the efficiency of such retail competition from whence it follows that . . . . these methods must be regarded as unfair methods of competition

It is submitted to the Court that this combination offer is as frankly violative of the law of fair competition - i.e., a competition in productive and selling effciency-as are the misrepresentations made by petitioner. In the face of methods of this character, it is impossible for competition to operate freely, bringing about that adjustment in relative strength and position of competing organizations, with consequent benefits to consumers in the form of quality, service and price, which it was the intention and will of society to provide in adopting as the basic theory of business organizaton, the principle of competition.9

It is believed not to be an exaggeration to say that the commission, giving careful consideration to the economic as well as legal aspects of unfair competition and possessed both of extraordinarily broad investigatory powers, and a highly trained staff of lawyers, economists, accountants and statisticians, will in the long run evolve sounder and more adequate criterions for the determination of what constitutes unfair competition than could possibly be developed through any other agency than an administrative body. It is, of course, true that the courts may refuse to follow the commission's construction and interpretation as well as they

- Annual Report of the Federal Trade Commission, 1918, p. 130.

- Sears Roebuck \& Co. vs. Federal Trade Commission, Brief and Argument for Respondent, United States Circuit Court of Appeals for the Seventh Circuit, pp. $99,101$. 
might refuse to follow that of the Department of Justice. It may be conceded, however, that there would be no loss in this respect from the employment of commission method as compared with the Department of Justice method. Moreover, as the findings of fact of the commission are conclusive if supported by testimony, and the commission is vested with the power to make orders on the basis of these facts, it is certainly to be presumed that the theories of the commission as to construction and interpretation will be treated with more consideration than would be accorded to the theories of the Department of Justice.

\section{Easy and Expeditious Procedure}

Another advantage of the commission's method of enforcement relates to the adequacy of the protection afforded business concerns through this method of procedure. It is, of course, true that the method of procedure through the Department of Justice would eliminate that lack of protection on account of the expense factor which is one of the principal objections to the method of preventing unfair methods through private right of action. And it is also true that the Department of Justice method would protect the general public interest in this matter in a fashion impossible under the private right of action. All these advantages of the Department of Justice method, however, are equally obtainable under the commission method. Any concern that is dissatisfied with the method of competition employed by its competitors may file a complaint with the commission which will investigate the same and, if the facts warrant, will proceed against the manufacturer or other concern using the unfair method in question.

Thus an easy, expeditious and inexpensive (from the standpoint of business organizations) method is provided for the correction of injuries suffered by concerns through such method and the complaint of the small concern will receive as much attention as the complaint of the large. Nor will the former's case fail for lack of funds to employ legal and other expert advice which may be necessary to prove the case, as might well be true were the sole remedy a private right of action in court to secure protection against the methods of competitors. Yet another important advantage of preventing unfair competition through an administrative body like the commission relates to the flexibility of administrative as compared with legal procedure. Where cases are handled by the 
Department of Justice and the courts, a long time must frequently elapse before the decision of the matter. Legal procedure is relatively both slow and technical as compared with the action of an administrative body. Moreover, it is possible for an administrative body to call in an entire industry if necessary as was done by the Federal Trade Commission in certain of the commercial bribery cases. Under rules of legal procedure it would probably be impossible in many cases for the Department of Justice to do this. Instead it would probably be necessary to file and try a complete series of separate suits one against each offending party.

\section{Orders of the Commission and Judictal Review}

There is yet another matter in connection with the administrative enforcement of the act that requires careful consideration. This is the question of how far and to what extent the orders of the commission will become subject to judicial review. This is important from several standpoints but especially so from that of the construction and interpretation of the act. If the orders of the commission are not contested or the commission is not forced to take them before the courts in order to secure their enforcement it follows that the constructions and interpretations of the commission will necessarily constitute the criterions for the determination of unfairness in the great majority of cases. These criterions will thus tend to become the ones recognized by business and the public as determining the fairness or unfairness of particular methods, and gradually they will become firmly established. It has been indicated that the commission, on account of factors previously discussed, is better equipped probably to develop a sound construction and interpretation of the term unfair methods of competition than any other governmental agency except an administrative body of the same character. During the four years since the organization of the commission there have been several indications that the commission's orders are not likely to be frequently contested. In many cases the parties engaged in certain methods of competition such as commercial bribery are only too glad to be rid of such practices and welcome a valid excuse for refusing to continue a system which they or at least the bulk of them dislike and abhor but continue to practice because practically forced to do so by the competition of other 
concerns. Secondly many practices complained of, such as passing off and misrepresentation, etc., are not only obviously unfair and uneconomic but are tinged to such an extent with the element of moral turpitude that few concerns have the hardihood to subject them to judicial review. In such cases offending parties are only too glad to take a finding and order without contest, and correct their practices.

The best evidence of the fact that judicial review is unlikely to be called for in more than a small proportion of cases under the administrative method of procedure lies in the record of the cases before the commission. Up to November 21, 1918, 876 applications for complaints had been received by the commission. Of these approximately one-half, 444 to be exact, were dismissed without public notice or knowledge while 213 more were under investigation. In the case of the balance of the applications, 219 in number, complaints were issued. Of this group 124 were disposed of, ten by dismissal, the respondents having made a sufficient defense, and 114 by orders to cease and desist. In 109 out of these 114 cases the orders were issued by and with the consent of the respondent and in the other five cases the action was tried and argued and resulted in the order. ${ }^{10}$ In only two cases to date have respondents appealed to the Circuit Court of Appeals against the order of the commission.

These facts lead to two conclusions: First, that certain methods complained against by the commission and against which orders are issued will never be defended by the parties employing them, and the orders of the commission in connection therewith will not become subject to judicial review, and second, that certain methods complained of by the commission will not be defended and no attempt will be made to defend them against the commission's order until orders against such practices have been so often issued and over such a long period of time that the method in question has come to be generally recognized as an unfair method of competition together with the reasons for so regarding it. In these ways and for the reasons mentioned it is believed that the construction of unfair methods of competition by the commission will tend to gradually establish itself in the law of

${ }^{10}$ W. B. Colver, Chairman, Address before the Commission Specialty Manufacturers' Association, Cleveland, November $21,1918$. 
the country and that this construction will be more adequate to preserve fair competition than would a construction evolved by any other than an administrative body of a similar character. Probably it is true that the commission would welcome judicial contests of its orders especially in border line cases where it is extremely difficult to determine the question of fairness or unfairness. The affirmative decision of the courts on the commissions orders would immediately set at rest the law on the contested methods, and adverse decisions would enable the commission to ask Congress for legislation to cover the methods thus upheld.

In conclusion, the belief may be expressed that the unprejudiced student of the commission's work will conclude that the commission has done remarkably well and that in a relatively short space of time it has accomplished a great deal in the way of freeing trade and competition from the throttling influence and effects of the numerous uneconomic and vicious practices embraced in unfair methods of competition. 